\title{
Driving Behaviour of Elderly Drivers in Malaysia
}

\section{Naida Rosli ${ }^{1}$, Kamarudin Ambak ${ }^{1 *}$, Nurfatin Nadiah Shahidan", Nur Sabahiah Abdul Sukor ${ }^{2}$, Sharifah Osman@Liew Shyuan $\mathrm{Yei}^{3}$}

\author{
${ }^{1}$ Smart Driving Research Centre, \\ Universiti Tun Hussein Onn Malaysia, 86400 Parit Raja, Johor, MALAYSIA \\ ${ }^{2}$ School of Civil Engineering, \\ Universiti Sains Malaysia, 14600 Nibong Tebal, Pulau Pinang MALAYSIA \\ ${ }^{3}$ Behaviour Analysis and Valuation Unit, \\ Malaysian Institute Road Safety Research, 43000 Kajang, Selangor, MALAYSIA \\ *Corresponding Author
}

DOI: https://doi.org/10.30880/ijie.2020.12.08.026

Received 12 October 2019; Accepted 01 April 2020; Available online 15 September 2020

\begin{abstract}
Aging of population has increased in most developed countries. In year 2030, the aging population in Malaysia will reach $15 \%$ of the population. This situation contributes to the increasing number of older drivers on the road. Thus, it is important to identify the needs and safety aspects of driving among the elderly. The objective of this study was to determine the characteristics of basic driving skills among older drivers and their driving behavior. An instrument adapted from Driver Behavior Questionnaire (DBQ) was used to collect survey data. A total of 240 car drivers aged 50 years and above completed the questionnaire. For observation data, 150 respondents were chosen in order to observe their driving skills especially at intersections and parking areas. A Correlation analysis and Chi-Square test were performed to study the relationship between their age and driving skills. Results showed majority of the respondents demonstrated that they had knowledge of basic driving skills. Observation study at parking areas showed that selection of parking space, in and out parking skills, time taken to park, vehicle position and number of passengers were significant towards gender. While, observation at intersections showed that only vehicle distance was significant towards gender. Three variables (the older drivers being comfortable driving on the left lane, older drivers were often honked during driving and older drivers being slow responding to hazards such as pedestrians at the crossing) were correlated and significant at $p<0.05$. This study recommended providing older drivers with priority lanes, special parking areas and car sticker tagging "older driver" in addition to supervising their licenses, conducting driving class sessions and undergoing medical examination for them.
\end{abstract}

Keywords: Elderly driver, behavior, driving skill, DBQ

\section{Introduction}

Senior citizens are defined as people aged 60 years and above according to the definition of "World Assembly on Ageing 1982" [1]. While, World Health Organization [2] classifies the definition of older people into three stages namely early stage ( 50 to 65 years), middle stage (65 to 75 years) and final stage ( 75 years and above). In Malaysia, the number of people aged 60 years and above is increasing while the population aged 15 years and below is decreasing [3][4]. Thus, the increasing number of senior citizens in society contributes to the increasing number of older drivers on 
the road. Driving is the easiest mode of transportation among of the older drivers because it helps them to move around and travel [5]. For the elderly, driving is a symbol of control, freedom and independence [6]. Therefore, the elderly drive to fulfill their basic and social needs such as obtaining food supply, getting healthcare protection and doing their social activities (e.g.: visiting friends and relatives).

However, the increasing number of older drivers has increased the risk of fatal accidents on the road because physical ability is decreasing in association with the increasing of age [7]. Few studies have been conducted by focusing on the older drivers' medical condition and disabilities that affect their driving performance and increase the risk of accidents among them. Older drivers have better skills and driving attitude than younger drivers do [8]. Furthermore, older drivers have better experience in driving, but due to age factor, their driving performance is affected [9]. Therefore, this study was carried out to identify the characteristics of basic driving skills among older drivers, to evaluate their driving behavior and to correlate between age factor and their driving behavior.

According to the statistic by the Royal Malaysian Police in 2016, older drivers aged 50 and above recorded about 2,288 cases $(32 \%)$ of accident rate [10][11]. One of the causes of accident among the elderly is from taking medication in which can affect their driving abilities and can lead to risk of accident [9]. Despite being able to adjust their driving, they may fail to control themselves properly at certain times while driving and can result in a high risk of violations or accidents [12][13]. To overcome this problem, several countries such as United Kingdom (UK) [16], Australia [14], United States of America (USA) [15] and Britain [16] have imposed special rules for driving license renewal among older drivers. This policy aims to reduce accident rate among the elderly.

The existing driving safety features nowadays can reduce the rate of accidents especially among older drivers. For example, by improvement of the driving environment on the road condition, reorganization of existing or new intersections such as roundabout to reduce vehicle speed and eliminate some of the most complicated aspects. Roundabouts can improve traffic flow and make it easier to control the traffic [17]. In addition, the existing vehicle technologies will facilitate the older drivers in controlling their vehicles. For example, In-Vehicle Navigation System (IVNS) is one of the navigation systems that can help to plan trips such as Google Maps [18]. Hence, the older drivers can avoid writing street addresses or map locations on papers which are placed on passenger seat as this can disrupt their focus while driving.

Thus, this study aimed to determine the characteristics and behavior of driving skills among the elderly. This study is expected to help authorities and professionals to develop strategies and efforts to increase safety driving among the elderly. This study was conducted in Malaysia by providing data for appropriate policies and strategies to mitigate this issue.

\section{Methodology}

\subsection{Sample Size}

This cross-sectional study method was carried out in Batu Pahat, Johor because this location has been identified as an area that has frequent traffic accidents in Johor [19]. In addition, Batu Pahat has reported the highest road accidents due to road environment [20] and human behavior. Department of Statistic Malaysia [21] has also recorded that Johor has the second highest number of populations among older peoples (50 years and above). Therefore, the characteristics of selected respondents were older drivers aged 50 years and above, defined as Elderly by World Health Organization [2] and who were still driving.

\subsection{Pilot Study}

Pilot study is a pre-testing or 'trying out' of a particular research instrument [22] and conducted before the actual study to determine the reliability of the questionnaire. Pilot study was conducted on 20 senior drivers as respondents. The internal consistency was applied to determine the reliability of items. All items with high correlation values show high reliability, while low correlation values show low reliability and need to be eliminated [23]. Common method used to determine internal reliability is Cronbach's Alpha coefficient [23]. The Cronbach's Alpha score obtained from the pilot study was 0.81 and acceptable reliability score is 0.65 to 0.95 [23]. Therefore, the questionnaire could be used for actual study.

\subsection{Data Collection Method}

\subsubsection{Survey Method}

The survey activities were carried out starting from March till April 2015. The 240 self-administered questionnaires were distributed to be filled by the respondents in Batu Pahat, Johor. Each older driver who was selected must complete the questionnaire and return it to the distributor. Only respondents who volunteered would be approached and those who did not cooperate would not be forced to do so. 


\subsubsection{Observation Method}

For observation method, the sample size of 150 respondents was needed [24]. Observations were carried out at the intersections and parking areas around Batu Pahat in order to observe how the elderly operating their vehicles and their driving patterns. Intersections were chosen as observation locations because Preusser et al. [25] stated that older drivers are commonly exposed to accident risk at intersections. This happens because older drivers make more evaluation errors in failure-to-yield crashes, and these errors generally occur when drivers see the other vehicles but misjudge whether there is enough time to proceed [26]. Furthermore, parking areas were selected as observation locations because older drivers face difficulty in parking and view it as a difficult driving task [27].

Observation method aimed to evaluate the real behavior of older drivers and was conducted by observing respondents at the intersections and parking areas. Physical characteristics at parking areas (selection on space, in and out parking skills, time taken to park, vehicle position and number of passengers) and at intersections (seatbelt wearing compliance, proper time to give turn signal, way of turning, vehicle distance and road environment) were marked in the specific form after the driver were identified as an elderly driver in order to collect the observation data. Then, the data gathered were analyzed using Statistical Package for Social Science (SPSS) version 22.0.

\subsection{Instrument and Measurement}

The questionnaire form was used to collect data and respondents' information. The Driver Behavior Scale was adapted based on Driver Behavior Questionnaire (DBQ) and divided into four parts; Part A: Respondent Information (Table 1, Gender, Race, Marital Status, Age, Occupation, License and Vehicle ownership), Part B: Respondent Experience (Table 1, Medication Taking, Driving Experience, Driving Frequency, Distance Traveled, Involvement with Road Accident, Police Summons and Weather Effect to Driving Behavior), Part C and D: Respondent's Opinion upon their basic skills and behavior during driving. Likert scale was used to measure and determine the category of items from scale of disagree to agree. Ratings were made upon the five points of the Likert Scale.

The Driver Behavior Scale (DBS) was adapted and designed based on Driver Behavior Questionnaire. Driver Behavior Questionnaire (DBQ) was designed and developed in Britain by Reason et al. [28]. DBQ has been used extensively in the attempt to measure risk-increasing driver behavior and to predict collision risk [29]. There are a few studies related to elderly drivers using DBQ as an instrument such as Koppel et al. [30], Gabaude et al. [31], Obriot Claudel [32].

\subsection{Statistical Analysis}

The analyses for cross-sectional survey were correlation and chi-square methods. Correlation method is designed to measure the strength of the linear relationship between two variables and Chi-square tests is to determine whether the case studies are significant $(p<0.05)$ or not significant $(p>0.05)$. The $p$ value indicates only 5 out of 100 times when repeated the study will give different results. In other words, only $5 \%$ of the study was different due to sampling and measurement errors [23]. Chua [23] stated that p-values are commonly set at 0.05, 0.01 and 0.005.

\section{Results and Analysis}

\subsection{Descriptive Data}

Descriptive data is based on the survey method that was conducted by distribution questionnaires to the older drives. The characteristics of respondents are presented in Table 1. Based on 240 respondents, majority of them were male $(67.9 \%)$ and the rest were female (32.1). Most of them were Malay (69.17\%), married (95.4\%), age 50-59 years $(57.9 \%)$, full license holder $(98.8 \%)$, and full ownership of their cars $(90.4 \%)$. Definitely, people at aged 50 years and above generally are married, have strong financial status and are able to have their own vehicles. Almost half of respondents were retired (30\%) and self-employed (26.3\%). This finding supported economy field definition that senior citizens are people who have retired from their career [32][4]. Medication taking among elderly drivers was mostly male $(57.9 \%)$. In addition, their experiences were also surveyed in order to relate them with their driving behavior such as driving experience and frequency, distance travelled, involvement with road accidents, police summons and weather effects to their driving behavior.

Table 2 shows the summary of the driving characteristics and skills among older drivers. The result showed that older drivers did have knowledge of basic driving skills as the majority of respondents indicated a positive opinion on items such as regularly checking on rear and side view mirrors before starting the journey, wearing seat belt, giving early signal when turning, preparing to stop or move when the light turns yellow, turning on light at night and having ability to park at the right position. For efficiency factors, elderly drivers agreed that they had difficulty when driving in certain situations such as rainy days, at night and on busy roads. However, they disagreed that they turned aggressively, were often honked while driving by other drivers and had difficulty and problem determining distance.

Confusion factor showed that elderly drivers disagreed that they were confused with the traffic movement especially at the junctions and the right to give way at the intersections without traffic lights. Whereas, comfort factor showed that elderly drivers were comfortable using left lane during driving. Finally, physiological factor indicated that 
most of the elderly drivers disagreed that they were easily bored and sleepy during a long journey, distracted during driving, tired in a short journey and slow in reacting toward unexpected hazards. In conclusion, they disagreed that the physiological factors would decrease their driving skills.

Table 1 - Characteristics of respondents $(n=240)$

\begin{tabular}{|c|c|c|}
\hline Demographic & Frequency(n) & $(\%)$ \\
\hline \multicolumn{3}{|l|}{ Gender } \\
\hline Female & 77 & 32.1 \\
\hline Male & 163 & 67.9 \\
\hline \multicolumn{3}{|l|}{ Race } \\
\hline Malay & 166 & 69.17 \\
\hline Chinese & 47 & 19.6 \\
\hline Indian & 27 & 11.3 \\
\hline \multicolumn{3}{|l|}{ Marital Status } \\
\hline Married & 229 & 95.4 \\
\hline Single & 11 & 4.6 \\
\hline \multicolumn{3}{|l|}{ Age (years) } \\
\hline $50-59$ years & 139 & 57.9 \\
\hline $60-69$ years & 80 & 33.3 \\
\hline$>70$ years & 21 & 8.8 \\
\hline \multicolumn{3}{|l|}{ Occupation } \\
\hline Private Sector & 23 & 9.6 \\
\hline Government Sector & 47 & 19.6 \\
\hline Self-Employed & 63 & 26.3 \\
\hline Retired & 72 & 30 \\
\hline Not Working & 35 & 14.6 \\
\hline \multicolumn{3}{|l|}{ License } \\
\hline Full (D) & 237 & 98.8 \\
\hline No License & 3 & 1.2 \\
\hline \multicolumn{3}{|l|}{ Vehicle Ownership } \\
\hline Own & 217 & 90.4 \\
\hline Family & 23 & 9.6 \\
\hline \multicolumn{3}{|l|}{ Medicine Taking } \\
\hline Male & 139 & 57.9 \\
\hline Female & 101 & 42.1 \\
\hline \multicolumn{3}{|l|}{ Driving Experience } \\
\hline$<2$ years & 3 & 1.3 \\
\hline 3-10 years & 4 & 1.7 \\
\hline $11-15$ years & 32 & 13.3 \\
\hline$>15$ years & 201 & 83.8 \\
\hline \multicolumn{3}{|l|}{ Driving Frequency } \\
\hline Everyday & 87 & 36.25 \\
\hline 1-2 per weeks & 58 & 24.17 \\
\hline 3-4 per weeks & 80 & 33.33 \\
\hline$<1$ month & 15 & 6.25 \\
\hline \multicolumn{3}{|l|}{ Distance Traveled } \\
\hline$<10 \mathrm{~km}$ & 119 & 49.6 \\
\hline $10-25 \mathrm{~km}$ & 99 & 41.3 \\
\hline$>25 \mathrm{~km}$ & 22 & 9.2 \\
\hline \multicolumn{3}{|l|}{$\begin{array}{l}\text { Involvement with road } \\
\text { accident }\end{array}$} \\
\hline Yes & 45 & 18.8 \\
\hline No & 195 & 81.25 \\
\hline
\end{tabular}




\section{Police Summons}

\begin{tabular}{lcc} 
Yes & 77 & 32.1 \\
No & 163 & 67.9 \\
$\begin{array}{l}\text { Weather Effect to driving } \\
\text { behavior }\end{array}$ & \\
Rain & & \\
Yes & 193 & 80.4 \\
No & 47 & 19.6 \\
Hot & & \\
Yes & 131 & 54.6 \\
No & 109 & 45.4 \\
Haze & & \\
Yes & 152 & 63.4 \\
No & 88 & 36.6 \\
\hline
\end{tabular}

Table 2 - Summary of the characteristics and skills of driving among of older drivers

\begin{tabular}{lcccc}
\hline Variables & Item & Average Score Mean & Std. Deviation & Results \\
\hline Basic Skills & 6 & 2.83 & 0.361 & Disagree \\
Efficiency Factor & 10 & 2.66 & 0.587 & Disagree \\
Confusion Factor & 7 & 2.69 & 0.759 & Disagree \\
Comfort Factor & 1 & 3.45 & 1.062 & Agree \\
Physiological Factor & 5 & 2.85 & 0.685 & Disagree \\
\hline
\end{tabular}

\subsection{Correlation Analysis}

Correlation analysis resulting from the survey data are presented in Table 3. It was conducted to see the relationship between age and behavioral factors. Therefore, this study conducted a hypothesis testing to determine the significance of these variables as below.

H1: SI (Turning aggressively at intersections without stopping vehicle) is significant positive impact on age.

H2: S2 (Often get honked when driving slowly) is significant positive impact on age.

H3: S3 (Comfortable using left lane during driving) is significant positive impact on age.

H4: S4 (Difficult to drive in certain situations such as rainy days, nighttime and on busy roads) is significant positive impact on age.

H5: S5 (Difficult to make a movement at minor to main intersection) is significant positive impact on age.

H6: S6 (Confused about the right of giving way at the intersection) is significant positive impact on age.

H7: S7 (Slow to react to unexpected hazard such as pedestrian crossing) is significant positive impact on age.

H8: S8 (Difficult to determine safe distance between others vehicle) is significant positive impact on age.

Table 3 - Correlation analysis between age and behavior factor

\begin{tabular}{ccccccccccc}
\hline & Age & S1 & S2 & S3 & S4 & S5 & S6 & S7 & S8 & S9 \\
\hline Age & 1 & & & & & & & & \\
S1 & -0.050 & 1 & & & & & & & \\
S2 & $-0.147^{*}$ & $0.319^{* *}$ & 1 & & & & & & \\
S3 & $0.145^{*}$ & 0.113 & $0.130^{*}$ & 1 & & & & & \\
S4 & 0.095 & 0.096 & $0.146^{*}$ & $0.278^{* *}$ & 1 & & & & \\
S5 & -0.002 & $0.264^{* *}$ & $0.172^{* *}$ & $0.222^{* *}$ & $0.151^{*}$ & 1 & & & \\
S6 & -0.097 & $0.180^{* *}$ & $0.281^{* *}$ & $0.285^{* *}$ & $0.193^{* *}$ & $0.284^{* *}$ & 1 & & \\
S7 & $-0.182^{* *}$ & $0.339^{* *}$ & $0.347^{* *}$ & $0.295^{* *}$ & $0.193^{* *}$ & $0.316^{* *}$ & $0.399^{* *}$ & 1 & \\
S8 & -0.083 & $0.338^{* *}$ & $0.376^{* *}$ & $0.345^{* *}$ & $0.211^{* *}$ & $0.338^{* *}$ & $0.520^{* *}$ & $0.560^{* *}$ & 1 & \\
S9 & -0.036 & $0.146^{*}$ & $0.157^{*}$ & $0.216^{* *}$ & $0.131^{*}$ & $0.245^{* *}$ & $0.187^{* *}$ & $0.318^{* *}$ & $0.364^{* *}$ & 1 \\
\hline
\end{tabular}

*. Correlation is significant at the 0.05 level (2-tailed).

**. Correlation is significant at the 0.01 level (2-tailed) 
Based on the values in the Table 3, there were a significant relationship between S2 (Often get honked when driving slowly), S3 (Comfortable using left lane during driving) and S7 (Slow to react to unexpected hazard such as pedestrian crossing) towards age. The relationship between S2 with age was very weak and negative $\left(\mathrm{r}=-.147^{*}\right)$ but significant relationship $(\mathrm{p}<0.05)$. While, relationship between S3 and age was positive, very weak $\left(\mathrm{r}=.145^{*}\right)$ and significant relationship $(\mathrm{p}<0.05)$. Lastly was relationship between S7 and age. The correlation value of S7 showed that this variable was very weak, negative and significant relationship towards age $(\mathrm{r}=-.182 * *, \mathrm{p}<0.01)$. Other variables which were S1 (Turning aggressively at intersections without stopping vehicle), S4 (Difficult to drive in certain situations such as rainy days, nighttime and on busy roads), S5 (difficult to make a movement during at minor to main intersection), S6 (confused about the right of giving way at the intersections), S8 (difficult to determine safe distance between others vehicle) and S9 (easy to feel bored and sleepy during a long journey) showed insignificant relationship towards age. Therefore, only $\mathbf{H 2}, \mathbf{H 3}$ and $\mathbf{H} 7$ were accepted.

Table 4 - Driving behaviour among elderly drivers

\begin{tabular}{cl}
\hline Items & \multicolumn{1}{c}{ Description } \\
\hline S1 & Turning aggressively at intersections without stopping vehicle \\
S2 & Often get honked when driving slowly \\
S3 & Comfortable using left lane during driving \\
S4 & Difficult to drive in certain situations such as rainy days, night-time and on busy roads \\
S5 & Difficult to make a movement at minor to main intersection \\
S6 & Confused about the right of giving way at the intersection \\
S7 & Slow to react to unexpected hazard such as pedestrian crossing \\
S8 & Difficult to determine safe distance between others vehicle \\
\hline
\end{tabular}

\subsection{Descriptive and Chi- Square Analysis}

Observation method was conducted at intersections and parking areas. The descriptive and chi-square analysis were chosen to demonstrate the observation result. Table 5 represents chi-square and descriptive analysis from observation data at intersection areas. Chi-square tests is to determine whether the case studies are significant $(\mathrm{p}<0.05)$ or not significant $(\mathrm{p}>0.05)$. Therefore, this study conducted a hypothesis testing to determine the significance of these variables as below.

H1: Wearing seatbelt is significant positive impact on gender.

H2: Giving signal on time when turning is significant positive impact on gender.

H3: Way of turning is significant positive impact on gender.

H4: Vehicle distance is significant positive impact on gender.

H5: Road environment is significant positive impact on gender.

Based on the result obtained, only vehicle distance showed significant towards gender $(\mathrm{p}<0.05)$. Therefore, only H4 was accepted. Descriptive results showed that majority of female respondents (87.7\%) had suitable distance between vehicles during driving at intersection compared to male respondents did (72.9\%). Table 6 demonstrates chisquare and descriptive analysis from observation data at parking areas. Therefore, this study conducted a hypothesis testing to determine the significance of these variables as below.

H1: Selection of parking space is significant positive impact on gender.

H2: In and out parking skills is significant positive impact on gender.

H3: Time taken to park is significant positive impact on gender.

H4: Vehicle position is significant positive impact on gender.

H5: Number of passengers is significant positive impact on gender

For variables of selection of parking space, in and out parking skills, time taken to park, vehicle position and number of passengers showed significance towards gender $(\mathrm{p}<0.05)$. Therefore, HI, H2, H3, H4 and H5 were accepted. Descriptive result showed that majority of male respondents were skillful (35\%) at parking areas such as taking a shorter time to park (70\%) and parking their vehicle in a good position $(74 \%)$. 
Table 5 - Summary of chi square and descriptive analysis (intersection)

\begin{tabular}{|c|c|c|c|c|c|c|}
\hline \multirow[t]{2}{*}{ Variables } & \multirow[t]{2}{*}{ Chi Square } & \multirow[t]{2}{*}{ p-value } & \multirow[t]{2}{*}{ df } & \multicolumn{3}{|c|}{$\begin{array}{c}\text { Descriptive } \\
\text { Frequency }(\%)\end{array}$} \\
\hline & & & & & Female & Male \\
\hline \multirow[t]{2}{*}{$\begin{array}{c}\text { Seatbelt } \\
\text { wearing } \\
\text { compliance }\end{array}$} & 1.046 & 0.306 & 1 & Buckling & $50(76.9 \%)$ & $59(69.4 \%)$ \\
\hline & & & & Unbuckling & $15(23.1 \%)$ & $26(30.6 \%)$ \\
\hline \multirow[t]{2}{*}{$\begin{array}{l}\text { Time to Give } \\
\text { Turn Signal }\end{array}$} & 2.635 & 0.105 & 1 & Early & $54(83.1 \%)$ & $61(71.8 \%)$ \\
\hline & & & & Late & $11(16.9 \%)$ & $24(28.2 \%)$ \\
\hline \multirow[t]{2}{*}{$\begin{array}{l}\text { Way of } \\
\text { turning }\end{array}$} & 1.952 & 0.162 & 1 & Normal & $55(84.6 \%)$ & $64(75.3 \%)$ \\
\hline & & & & Aggressive & $10(15.4 \%)$ & $21(24.7 \%)$ \\
\hline \multirow[t]{2}{*}{$\begin{array}{l}\text { Vehicle } \\
\text { Distance }\end{array}$} & 4.888 & $0.027 *$ & 1 & $\begin{array}{l}\text { Suitable } \\
\text { distance }\end{array}$ & $57(87.7 \%)$ & $62 / 72.9 \%$ \\
\hline & & & & $\begin{array}{c}\text { Unsuitable } \\
\text { distance }\end{array}$ & $8(12.3 \%)$ & $23(27.1 \%)$ \\
\hline \multirow[t]{2}{*}{$\begin{array}{c}\text { Road } \\
\text { Environment }\end{array}$} & 1.527 & 0.217 & 1 & Yes & $49(75.4 \%)$ & $71(83.5 \%)$ \\
\hline & & & & No & $16(24.6 \%)$ & $14(16.5 \%)$ \\
\hline
\end{tabular}

Table 6 - Summary of chi square and descriptive analysis (parking area)

\begin{tabular}{|c|c|c|c|c|c|c|}
\hline \multirow[t]{2}{*}{ Variables } & \multirow[t]{2}{*}{ Chi Square } & \multirow[t]{2}{*}{ p-value } & \multirow[t]{2}{*}{ df } & \multicolumn{3}{|c|}{$\begin{array}{c}\text { Descriptive } \\
\text { Frequency }(\%)\end{array}$} \\
\hline & & & & & Female & Male \\
\hline \multirow[t]{2}{*}{$\begin{array}{c}\text { Selection } \\
\text { parking Space }\end{array}$} & 5.671 & $0.017 * *$ & 1 & $\begin{array}{l}\text { Quiet and } \\
\text { remote area }\end{array}$ & $31(51.7 \%)$ & $29(32.3 \%)$ \\
\hline & & & & Full area & $29(48.3 \%)$ & $61(67.8 \%)$ \\
\hline \multirow[t]{2}{*}{$\begin{array}{c}\text { In and out } \\
\text { parking skills }\end{array}$} & 17.898 & $0.000 * * *$ & 1 & proficient & $21(35.0 \%)$ & $63(70 \%)$ \\
\hline & & & & Normal & $39(65 \%)$ & $27(30 \%)$ \\
\hline \multirow[t]{2}{*}{$\begin{array}{c}\text { Time taken to } \\
\text { park }\end{array}$} & 17.898 & $0.000 * * *$ & 1 & Short & $21(35 \%)$ & $63(70 \%)$ \\
\hline & & & & Long & $60(65 \%)$ & $27(30 \%)$ \\
\hline \multirow[t]{2}{*}{$\begin{array}{l}\text { Vehicle } \\
\text { position }\end{array}$} & 32.427 & $0.000 * * *$ & 1 & Good & $22(36.7 \%)$ & $74(82.2 \%)$ \\
\hline & & & & Poor & $38(63.3 \%)$ & $16(17.8 \%)$ \\
\hline \multirow[t]{2}{*}{$\begin{array}{l}\text { Number of } \\
\text { passengers }\end{array}$} & 11.182 & $0.001 * * *$ & 1 & $\begin{array}{c}\text { With } \\
\text { passengers }\end{array}$ & $38(63.3 \%)$ & $78(86.7 \%)$ \\
\hline & & & & $\begin{array}{c}\text { No } \\
\text { passenger }\end{array}$ & $22(36.7 \%)$ & $12(13.3 \%)$ \\
\hline
\end{tabular}

\section{Discussion}

This study reported the correlation between the characteristic of basic driving skills and driving behavior with age factors of older drivers. Descriptive analysis result demonstrated that most of respondents were male compared to female. In fact, every year male driver records the highest number registering with the road transport department compared to female driver [11]. Furthermore, descriptive result showed that elderly drivers seem to have a strong basic driving skill because most of them were full license (D) holder with driving experience of more than 15 years and drove everyday on the road. However, having a strong basic driving skills and experience among them did not mean that they had a good performance and practice safety during driving. A reason for this is age because it is associated with cognitive decline [33]. The declines are in term of having a short-term memory, low in visualization and solving 
problem skill which can affect their driving abilities [34]. Besides, most of the respondents recorded that they were taking medication especially among male older drivers. MacLenan [35] study indicated that taking medicines during driving will affect driving ability among senior citizens. Therefore, they need to ensure that to be able to drive safely; they are not taking any medicine which has potential to affect their driving performance such as sleepiness, drowsiness and others.

Elderly drivers agreed that they always buckled up their seat belts during driving, regularly checked the rear view and side mirror before starting any journey, gave signal early when turning and prepared to stop or move when the traffic light turned yellow. These were proven through observation results at the intersections and parking areas where most elderly drivers buckled up their seatbelt, gave early signal when turning and parked their vehicles in a good position. This indicates that elderly drivers were concerned about safety during driving. Finding related to seatbelt are consistent with Hanna and Hershman [36] study which states that the usage of seat belts has proven to have a positive effect in reducing chest injuries among all age groups, especially the elderly. Besides, basic driving skills should be practiced for safety and the observation data proved that most of male drivers were more skillful in term of vehicle distance and when in parking situation.

In term of efficiency factor, older drivers responded a positive feedback which means that they were still efficient during driving. This can also be amplified through observation data in which majority of elderly drivers turned the vehicle normally, maintained suitable gaps with other vehicles while driving and were aware of the road environment before turning.

They also disagreed that there were factors of confusion on the road because most of respondents had driving experience of more than 15 years and were familiar with the situation on the road. Respondents also stated that they were comfortable driving on the left lane because older people prefer to drive in a relaxing situation without speeding their cars. This result was also consistent with correlation analysis between S3 (comfortable using left lane during driving) and age factor. It demonstrates that these two variables have significant positive relationship which means that age affects the usage of left lane and the higher the age, the higher the usage of left lane.

The reason why elderly drivers were comfortable to use left lane is because they were often honked during slow driving and this is consistent with significant relationship between S2 (Often get honked when driving slowly) and age factor. They also disagreed that physiological factors affected their driving performance. However, it was likely that some of them were having physiological problems because due to Hakamies et al. [37] indicates that older drivers are easily exhausted and not able to concentrate during driving. The evidence from correlation analysis S7 (slow to react with unexpected hazard such as pedestrian crossing) proves that age factor affects response towards hazards. Thus, being easily exhausted will affect older drivers' concentration during driving which can lead to risk of accident because they are slow to react to unexpected hazards.

\section{Conclusion}

The characteristics of basic skills and driving behavior among elderly drivers are determined. Findings showed older drivers had strong knowledge of basic driving skills as majority of respondents indicated positive opinion of the following items such as regularly checking the rear view and side mirrors before starting a journey, buckling up their seatbelt, giving early signal when turning and were prepared to stop or move when the traffic light turned yellow. Correlation result demonstrated that age factor had a significant relationship with driving behavior of older drivers (often get honked when driving slowly, comfortable using left lane during driving and slow to react to unexpected hazards such as pedestrian crossing).

Observation data at intersections presented that only vehicle distance showed significant towards gender. While, observation data at parking areas showed that selection of parking space, in and out parking skills, time taken to park, vehicle position and number of passengers were significant towards gender $(p<0.05)$. Therefore, this study can be used in the future as a reference and to enhance the study of older drivers' driving characteristics and skills. This study recommended providing older drivers with priority lanes, special parking areas and car sticker tagging "older driver" in addition to supervising their licenses, conducting driving class sessions and undergoing medical examination for them.

\section{Acknowledgement}

The author would like to thank Research Management Center, Universiti Tun Hussein Onn Malaysia for funding this study under GPPS Research Grant Vot. H010. Also, thanks to Faculty of Civil Engineering and Built Environment, Universiti Tun Hussein Onn Malaysia and Smart Driving Research Center for support and providing facilities to conduct this study.

\section{References}

[1] Jabatan Kebajikan Masyarakat. Warga Emas. Portal Jabatan Kebajikan Masyarakat. Retrieved on September 27, 2018 from http://www.jkm.gov.my. 
[2] World Health Organization (2008). Ageing-friendly primary healthcare center toolkits. Retrieved on September 29, 2014 from http://www.who.int/ageing.

[3] Jabatan Kebajikan Masyarakat (2014). Portal Jabatan Kebajikan Masyarakat. Retrieved on June 23, 2018 from http://www.jkm.gov.my.

[4] Ismail, N. S. A., Abdullah, N., Hassan, K., Samsudin, S., Ahmad Zakuan, U. A., Yusof, R. \& Mohamed Zaki, N. (2017). Kesejahteraan hidup warga emas: Perancangan berasaskan gender. Malaysia Journal of Society and Space, 13, 75-85.

[5] Coughlin, J. (2001). Transportation and Older Persons: Perceptions and Preferences: A Report on Focus Groups. AARP Public Policy Institute.

[6] Whelan, M., Langford, J., Oxley, J., Koppel, S. \& Charlton, J. (2006). The Elderly and Mobility: A Review of The Literature. Monash University; Accident Research Centre.

[7] Dotzauer, M., Caljouw, S. R., Waard, D. D. \& Brouwer, W. H. (2013). Intersection assistance: A safe solution for older drivers? Accident Analysis and Prevention Journal, 59, 522-528.

[8] Charles, M. \& Haddad, H. (2010). Exploring older driver perception of driving European. Journal of Ageing, 7, 181-188.

[9] McGwin, G., Richard V. S., Pulley, L. V. \& Roseman, J. M. (1999). Relations among chronic medical conditions, medications, and automobile crashes in the elderly: A population-based case-control study. American Journal of Epidemiology, 152, 424-43.

[10] Polis Diraja Malaysia. Laporan Perangkaan Malaysia 2016. Kuala Lumpur: Bukit Aman Police Head Quarters.

[11] Jabatan Keselamatan Jalan Raya (2018). Buku Statistik Keselamatan Jalan Raya. Kuala Lumpur: Kementerian Pengangkutan Malaysia.

[12] Oxley, J., Fildes, B., Corben, B. \& Langford, J. (2003). Intersection design for older drivers. Transportation Research Part F, 9, 335-346.

[13] Ambak, K., Basil, D. D., Mamat, Z., Prasetijo, J. \& Rohani, M. (2016). The effect locus of control on driving behaviour among Malaysian young drivers. ARPN Journal of Engineering and Applied Sciences, 11, 1181211814

[14] Langford, J., Fitzharris, M., Newstead, S. \& Newstead, S. K. (2004). Some consequneces of different older driver licensing procedures in Australia. Accident Analysis and Prevention, 36, 993-1001.

[15] Insurance Institute for Highway Safety (2018). Older driver, licence renewal procedures. Retrieved on September 30, 2018 from https://www.iihs.org/iihs/topics/laws/olderdrivers?topicName=older-drivers.

[16] Christopher, G. B. \& Mitchell, K. (2013). The licensing and safety of older drivers in Britain. Accident Analysis and Prevention, 50, 732-741.

[17] Richard, A. R., Sergey, Y. K. \& McCart, A. T. (2008). long-term trends in public opinion following construction of roundabouts. Journal of the Transportation Research Board, 2019, 219-224.

[18] Emmerson, C., Guo, W., Blythe, P., Namdeo, A. \& Edwards, S. (2013). Fork in the road: In vehicle navigation systems and older drivers. Journal of Transportation Research Part F, 21, 173-180.

[19] Mohd Solhi, N. S. \& Yusof, Y. (2014). Kesan pembangunan jalan raya terhadap pembangunan jalan raya pembelajaran pelajar dari aspek keselamatan. Proc. of the $8^{\text {th }}$ Malaysian Technical Universities Conference on Engineering and Technology, Melaka, Malaysia.

[20] Che Him N., Roslan N., Rusiman M. S., Khalid K., Kamardan M. G., Arobi, F. A. \& Mohamad, N. (2018). Factor affecting road traffic accident at Batu Pahat Johor, Malaysia. Journal of Physics, 995, 012033.

[21] Department of Statistic Malaysia (2018). Population quick info. Retrieved on November 15, 2018 from http http://pqi.stats.gov.my/result.php?token=d5c6acbfd34bf5aebb2ab080b9e6536f

[22] Baker, T. L. (1994). Doing Social Research. New York: McGraw-Hill Inc.

[23] Chua, Y. P. (2014). Kaedah dan Statistik Penyelidikan Buku 2: Asas Statistik Penyelidikan. Kuala Lumpur: Mc Graw Hill Education.

[24] Koppel, S., Charlton, J., Fildes, B. (2009). Distraction and The Older Driver, In Drive Distraction: Theory, Effects and Mitigation. London: CRC Press.

[25] Preusser D. F., Williams A. F., Ferguson S. A., Ulmer R. G. \& Weinstein, H. B. (1998). Fatal crash risk for older drivers at intersections. Accident Analysis and Prevention, 10, 151-159.

[26] Braitman, K. A., Kirley, B. B., Ferguson, S. \& Chaudhary, N. K. (2007). Factors leading to older drivers' intersection crashes. Traffic Injury Prevention, 10, 267-274.

[27] Marshall, D., Smith, K. \& Chyrsler, S. (2014). Older drivers' acceptance of in-vehicle systems and the effect it has on safety. Final Report MATC-UI: 217 (2014), Mid America Transportation Centre, University of Iowa.

[28] Reason, J. T., Manstead, A., Stradling, S G., Baxter, J. \& Campbell, K. (1990). Errors and violations on the road a real distinction. Ergonomics, 33, 1315-1332.

[29] Cordazzo, S. T. D., Scialfa C., Bubric, K. \& Ross, J. R. (2014). The driver behaviour questionnaire: A North American analysis. Journal of Safety Research, 50, 99-111. 
[30] Koppel, S., Stephens, A. N., Charlton, J. L., Di Stefano, M., Darzins, P., Odell, M. \& Marshall, S. (2018). The driver behaviour questionnaire for older drivers: Do errors, violations and lapses change over time? Accident Analysis and Prevention, 113, 171-178.

[31] Gabaude, C., Marquié, J. C. \& Obriot-Claudel, F. (2010). Self-regulatory driving behaviour in the elderly: Relationships with aberrant driving behaviours and perceived abilities. Le Travail Humain 2010/1, 73, 31-52.

[32] Obriot-Claudel, F. \& Gabaude, C. (2004). The driver behaviour questionnaire: A French study applied to elderly drivers. Proceeding of the 3rd International Conference on Traffic and Transportation Psychology, Indiana, United States.

[33] Kim, B. J. \& Oh, S. H. (2013). Age-related changes in cognition and speech perception. Korean Journal of Audiology, 17, 54-58.

[34] Chang, H. J., Alison, E. \& Burke. (2013). Older driver and cognitive impairment. Journal of the American Medical Association, 13, 1-10.

[35] McLennan, P. A., Owsley, C., Rue, L. \& McGwin, G. (2009). Older adults knowledge about medications that can impact driving. Retrieved on September 29, 2014 from https://www.aaafoundation.org.

[36] Hanna, R. \& Hershman, L. (2009). Evaluation of Thoracic Injuries among Older Motor Vehicle Occupants. National Highway Traffic Safety Administration. Virginia: Springfield.

[37] Hakamies, B. T., Siren, A. \& Davidse, R. (2014). Older Drivers-A Review. Sweedish National Road and Transport Research Institute. 